\title{
Diet composition of Plagioscion squamosissimus (Heckel, 1840), a fish introduced into the Tietê River system
}

\author{
Stefani, PM. ${ }^{\mathrm{a} *}$ and Rocha, $O .^{\mathrm{b}}$

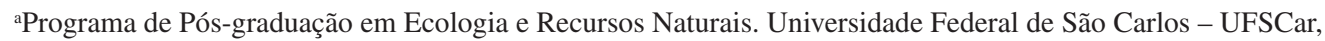 \\ Rod. Washington Luis, Km 235, CEP 13565-905, São Carlos, SP, Brazil \\ bDepartamento de Ecologia e Biologia Evolutiva, Universidade Federal de São Carlos - UFSCar, \\ Rod. Washington Luis, Km 235, CEP 13565-905, São Carlos, SP, Brazil \\ *e-mail: pat_stef@hotmail.com
}

Received December 13, 2007 - Accepted April 9, 2008 - Distributed August 31, 2009

(With 4 figures)

\begin{abstract}
Plagioscion squamosissimus is a species from the Amazon basin that was introduced into the Tietê River system. The present study aimed to analyse the feeding habits of this species in Bariri Reservoir and to verify the possible occurrence of ontogenetic changes in its diet composition. The samples were gathered in four periods of the year: February, June, September and November 2003. The fish were gathered with different fishing net meshes in three different reservoir portions. The alimentary items found in the stomachs were identified to the lowest possible taxonomic level and had abundance, occurrence frequency, volume and biomass determined. The Alimentary Index (IAi) was calculated for each alimentary item consumed by "corvina" for each studied period. Comparisons among the diet of different size classes of $P$. squamosissimus were done using the similarity coefficient of Jaccard and the Cluster Analysis (UPGMA). The Friedman proof was performed to verify if there is a significant ontogenetic variation in the species diet and changes in the consumption of different alimentary categories by $P$. squamosissimus among the sampled periods. . squamosissimus presented a piscivorous feeding habit, although other items were also consumed. The biggest values of IAi were obtained for the alimentary item fish in the months of June (0.47) and November (0.39). The item Ephemeroptera (Campsurinae) was the most representative in February (0.30) and June (0.45). Despite the fact that $P$. squamosissimus consumed an ample spectrum of alimentary items, the ontogenetic changes were evident through the exploration of aquatic insects by the younger classes and by a diet mainly composed of fish in adult individuals. The alimentary plasticity of $P$. squamosissimus evidenced in this study might have contributed to the success of this species in Bariri Reservoir.
\end{abstract}

Keywords: fish diet, "corvina”, Plagioscion squamosissimus, introduced species.

\section{Composição da dieta de Plagioscion squamosissimus (Heckel, 1840), um peixe introduzido no sistema do Rio Tietê}

\begin{abstract}
Resumo
Plagioscion squamosissimus é uma espécie da Bacia Amazônica que foi introduzida no sistema do Rio Tietê. O presente estudo teve como objetivo analisar o hábito alimentar da espécie no reservatório de Bariri e verificar possível ocorrência de mudanças ontogenéticas na composição da dieta. As amostragens foram realizadas em quatro períodos do ano: fevereiro, junho, setembro e novembro de 2003. Os peixes foram coletados com redes de diferentes malhagens em três porções do reservatório. Os itens alimentares encontrados nos estômagos foram identificados até o menor nível taxonômico possível e tiveram abundância, frequência de ocorrência, volume e biomassa determinados. O Índice de Importância Alimentar (IAi) foi calculado para cada item alimentar consumido pela corvina para cada período estudado. Comparações entre as dietas das diferentes classes de tamanho de $P$. squamosissimus foram feitas utilizando-se o coeficiente de similaridade de Jaccard e a Análise de Cluster. A Prova de Friedman foi realizada para verificar se há variação ontogenética significante na dieta da espécie e se existem mudanças no consumo das categorias alimentares nos períodos amostrados. P. squamosissimus apresentou um hábito alimentar piscívoro, embora outros itens alimentares também tenham sido consumidos. Os maiores valores do IAi foram obtidos para o item alimentar peixes nos meses de junho $(0,47)$ e novembro $(0,39)$. O item Ephemeroptera foi mais representativo em fevereiro $(0,30)$ e junho $(0,45)$. Apesar do fato de $P$. squamosissimus consumir um amplo espectro de itens alimentares, as mudanças ontogenéticas
\end{abstract}


ficaram evidentes pela exploração de insetos aquáticos pelas classes mais jovens e por uma dieta principalmente composta por peixe em indivíduos adultos. A plasticidade alimentar de $P$. squamosissimus evidenciada neste estudo pode ter contribuído para o sucesso da espécie nesse reservatório.

Palavras-chave: alimentação de peixes, corvina, Plagioscion squamosissimus, espécies introduzidas.

\section{Introduction}

The presence of humans in natural environments leads, in practically all cases, to the introduction of animal and plant species, whether intentionally or accidentally. In either case, the introduction leads to partial or total extinction of native species or is immediately followed by alterations in the trophic chain, balance of natural populations, or ecological processes (Espindola et al., 2003; Rocha et al., 2005).

Among animals, fishes are the most frequently introduced species, being transplanted from one hydrographic basin to others, in the same or even different continents (Rocha et al., 2005). In the reservoirs of the Tietê River, São Paulo State, Brazil, a number of species have been introduced (Smith et al., 2005). One of these, Plagioscion squamosissimus (Heckel, 1840), native to the Amazon basin, was introduced in São Paulo in 1966 by the Hydroelectric Company, initially into the rivers Pardo, Grande and Paraná, as well as the Ilha Solteira and Jupiá reservoirs, from which they colonised the Tietê River reservoirs (Braga, 1998; Agostinho and Júlio Jr., 1999).

Transplanting species from one basin to the other can represent a menace to the local species. Introduced fish may be better adapted to or more tolerant of the environmental conditions, thus achieving higher growth and reproductive output (Espindola et al., 2003). Some introduced species may hybridise with native closely related species, competing for food and space for reproduction. They can also carry disease agents (pathogens and parasites) (Rocha et al., 2005). Competition for food is, however, the main way in which introduced species affect native ones (Agostinho et al., 1994).

From data on the feeding habits of fishes, including not only the composition but also the abundance of food items, it is possible to identify trophic categories and draw inferences about community structure that shed light on inter-relationships between components of the community (Agostinho et al., 1997).

Trophic ecology studies reveal a considerable plasticity in the diet of most teleosts (Abelha et al., 2001). Most fishes can switch from one food item to another as soon as alterations in food availability occur (Hahn et al., 1997; Agostinho and Júlio Jr., 1999; Wooton, 1999), so that diet composition may reflect food availability in the environment (Wooton, 1999).

Dietary changes may be related to seasonality in food availability, ontogenetic changes or changes in the food spectrum (niche width) in the presence of other species (Lowe-McConnell, 1987).
According to Braga and Braga (1987) the changing food habit of a species during its development is an adaptation intended to diminish intra-specific competition or to satisfy physiological demands that the fish might have, due to migration, sexual maturation and reproduction.

The aim of the present study was to characterise the food consumed by Plagioscion squamosissimus ("corvina") and to determine whether there are changes in the items consumed attributable to ontogenetic changes, in Bariri Reservoir, Middle Tietê River basin, São Paulo State, Brazil.

\section{Study Area}

Álvaro de Souza Lima (Bariri) reservoir was formed by the damming of the Tietê River in 1965. It is the second from top of a cascade of six reservoirs in the system (Figure 1). It is located at $22^{\circ} 06^{\prime} \mathrm{S}$ and $48^{\circ} 45^{\prime} \mathrm{W}$, at $420 \mathrm{~m}$ altitude (Cesp, 1998).

The reservoir has: 5,546 ha flooded area; $35,430 \mathrm{~km}^{2}$ catchment area; $8.6 \mathrm{~m}$ mean depth; 7-24 days residence time and an annual mean discharge of $443 \mathrm{~m}^{3} / \mathrm{s}$. It belongs to the Tietê basin, a part of La Plata basin. The reservoir is located in the northwestern part of São Paulo State, between the towns Bariri and Boracéia.

\section{Methods}

Sampling was carried out in four periods of the year: February, June, September and November of 2003, which cover the dry (June/September) and wet (February/ November) seasons. Fishes were sampled in three portions of the reservoir: upper, middle and lower (near the dam). At each sampling site, three batteries of gill nets were used, containing mesh sizes of: 3, 4, $6,8,10$ and $11 \mathrm{~cm}$ opposite knots. Nets were placed in the reservoir and left for 12 hours. Species caught and respective numerical abundances were recorded in the field and specimens were then preserved in $10 \%$ formaldehyde solution. At the laboratory they were measured (total and standard length) and weighed.

Fish stomachs were removed, weighed and their content preserved. Food items were observed under stereomicroscope and identified down to the lowest taxonomical level possible, using available keys and with the help of specialists.

The method of Hynes (1950) was used to express the frequency of occurrence of the different food items in P. squaтоsissimus diet. 


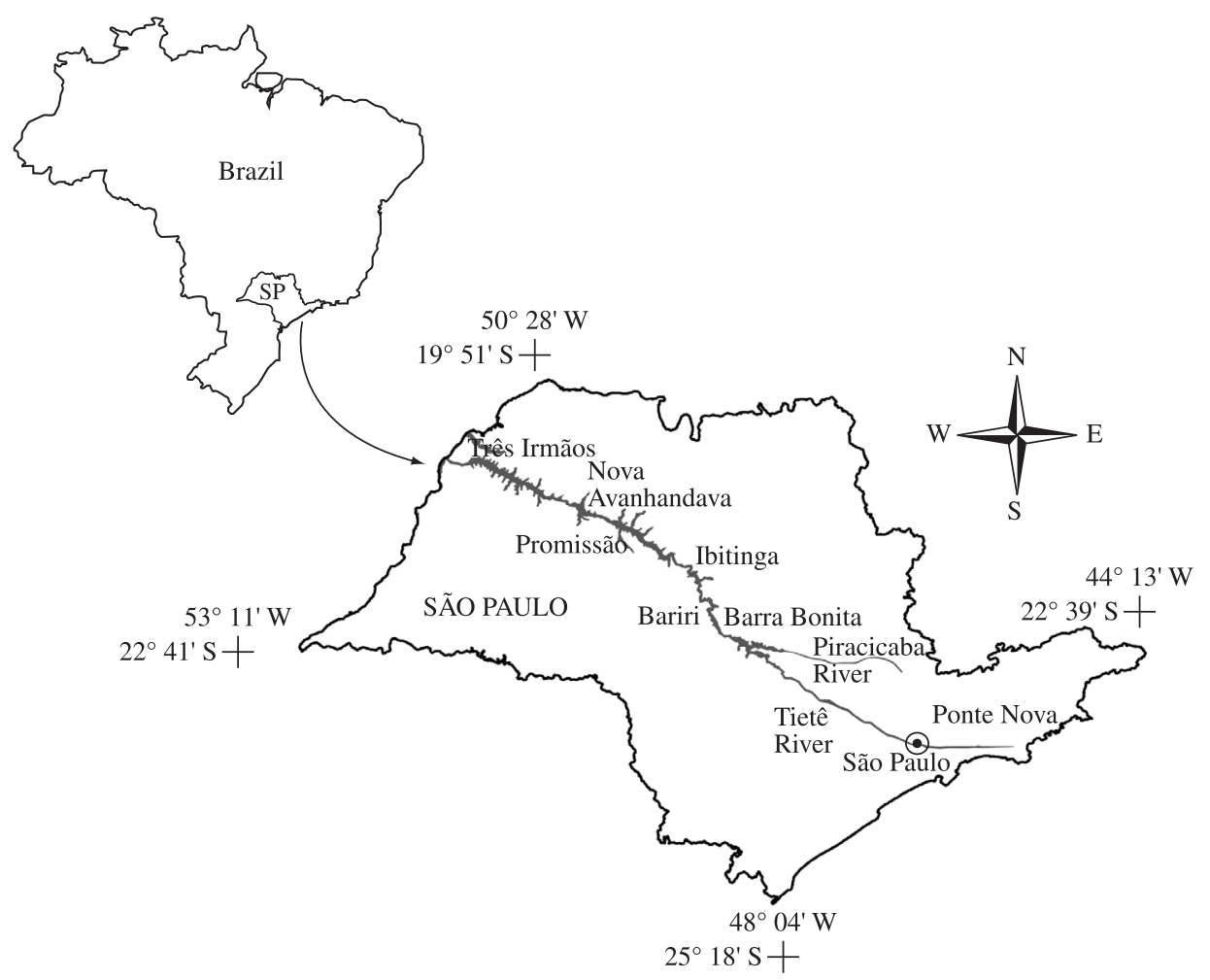

Figure 1. Map of São Paulo State showing the location of Bariri Dam and a sketch showing the cascade of reservoirs on Tietê River, São Paulo state, Brazil.

Food item volumes were obtained by volume displacement, using 10 and $30 \mathrm{~mL}$ graduated cylinders (Hyslop, 1980). The relative contributions of the individual food items were also determined as biomass dry weight, by the gravimetric method (Hyslop, 1980). The dry weight of Diptera consumed was estimated with the conversion factor $0.0063 \mathrm{mg}$ (Chironomidae weight value), from Prat and Rieradevall (1995).

In order to evaluate the relative importance of each item in the diet of $P$. squamosissimus in the four studied periods, the percentage values obtained for the frequency of occurrence $(\% \mathrm{~F})$ and biomass $(\% \mathrm{P})$ were combined in an Alimentary Index (IAi) as suggested by Kawakami and Vazzoler (1980), although replacing volume by the dry weight of each item.

In order to analyse if there were significant seasonal differences in the diet among $P$. squamosissimus size classes and among the four periods of the year in Bariri Reservoir, food items were grouped in the following categories: Fish, Ephemeroptera, Odonata, Trichoptera, Crustacea, Diptera, Insect fragments, Plant material and Detritus.

Ontogenetic differences in $P$. squamosissimus diet were analysed by separating the individual in different size classes (standard length) by Sturges method (1926). The seven size classes were compared with regard to the presence or absence of food items, by using the Jaccard index and then by the Cluster Analysis (UPGMA). The
Friedman Test (Siegel and Castellan, 2006) was applied to the occurrence frequency of food items in order to verify if there were ontogenic changes in the species dietary. The null hypothesis tested is that there is no difference among the species population size classes regarding the food categories consumed. The alternative hypothesis is that all size classes present preference for some food categories. Only those size classes that consumed at least three food categories were included in the test. This same test was used in order to check if there were significant seasonal differences in the food categories consumed by $P$. squamosissimus regarding the different sampling periods in the Bariri reservoir. The null hypothesis is that there are no differences in the preference by food categories when comparing the items consumed in the different periods. The alternative hypothesis is that there are significant differences in the food categories consumed by $P$. squamosissimus population in the different periods of the year. The significance of the values obtained was verified using the chi-square test of critical values.

\section{Results}

Stomach contents of 258 specimens of Plagioscion squamosissimus were analysed and 184 stomachs were found to contain food, while 74 were empty. The overall pattern of frequency of occurrence varied markedly (Table 1). Ephemeroptera (Campsurinae fragments) were 
Table 1. Contribution by abundance, frequency of occurrence $(\% \mathrm{FO})$, displaced volume $(\mathrm{mL})$ and dry weight $(\mathrm{g})$ of food items to the overall diet of Plagioscion squamosissimus in sampled in four periods of the year 2003 (February, June, September and November) in Bariri reservoir, Tietê River basin, São Paulo State, Brazil.

\begin{tabular}{|c|c|c|c|c|}
\hline Alimentary items & Abundance & FO (\%) & $\begin{array}{c}\text { Displaced } \\
\text { volume }(\mathrm{mL})\end{array}$ & $\begin{array}{c}\text { Dry weight } \\
\text { (mg) }\end{array}$ \\
\hline \multicolumn{5}{|l|}{ Fish } \\
\hline Fish flesh fragments & - & 33.60 & 55.10 & 7600 \\
\hline Fish (unidentified) & 68 & 10.30 & 32.30 & 2700 \\
\hline Plagioscion squamosissimus (fish fry) & 32 & 1.60 & 27.50 & 3050 \\
\hline Cichlidae & 26 & 1.60 & 1.50 & 150 \\
\hline Siluriformes & 3 & 0.50 & 0.40 & 30 \\
\hline Subtotal & 129 & - & 116.8 & 13530 \\
\hline \multicolumn{5}{|l|}{ Ephemeroptera } \\
\hline Campsurinae fragments (nymphs) & - & 36.40 & 22.30 & 1800 \\
\hline Egg mass & - & 14.60 & 14.90 & 2700 \\
\hline Subtotal & - & - & 37.2 & 4500 \\
\hline \multicolumn{5}{|l|}{ Odonata } \\
\hline Phyllocycla sp. (nymphs) & 5 & 3.80 & 1.60 & 210 \\
\hline Libellulidae (nymphs) & 3 & 1.60 & 1.00 & 70 \\
\hline Odonata nymphs fragments & - & 0.50 & 0.40 & 10 \\
\hline Subtotal & 8 & - & 3 & 290 \\
\hline \multicolumn{5}{|l|}{ Diptera } \\
\hline Chironomidae (pupae) & 33 & 7.60 & $<0.1$ & - \\
\hline Coelotanypus sp. (larvae) & 11 & 4.30 & $<0.1$ & 0.069 \\
\hline Ablabesmyia sp. (larvae) & 10 & 2.10 & $<0.1$ & 0.063 \\
\hline Cryptochironomus sp. (larvae) & 5 & 2.10 & $<0.1$ & 0.031 \\
\hline Chaoborus sp. (larvae) & 3 & 1.60 & $<0.1$ & 0.018 \\
\hline Chaoborus sp. (pupae) & 1 & 1.60 & $<0.1$ & - \\
\hline Ceratopogonidae (larvae) & 3 & 1.60 & $<0.1$ & 0.018 \\
\hline Asheum sp. (larvae) & 1 & 0.50 & $<0.1$ & 0.0063 \\
\hline Brundiniella sp. (larvae) & 1 & 0.50 & $<0.1$ & 0.0063 \\
\hline Goeldichironomus sp. (larvae) & 2 & 0.50 & $<0.1$ & 0.012 \\
\hline Harnischia sp. (larvae) & 1 & 0.50 & $<0.1$ & 0.0063 \\
\hline Subtotal & 71 & - & - & 0.229 \\
\hline \multicolumn{5}{|l|}{ Zooplankton } \\
\hline Notodiaptomus sp. (Copepoda Calanoida) & 3 & 1.08 & $<0.1$ & 0 \\
\hline Calanoida fragments & - & 0.5 & $<0.1$ & 0 \\
\hline Subtotal & 3 & - & - & - \\
\hline \multicolumn{5}{|l|}{ Others } \\
\hline Trichoptera (larvae) & 16 & 1.08 & 0.40 & 180 \\
\hline Macrobrachium sp. (Crustacea) & 1 & 0.5 & 1.20 & 200 \\
\hline Plant material & - & 12.5 & 1.50 & 40 \\
\hline Detritus & - & 0.5 & 0.20 & 6 \\
\hline Insect fragments & - & 5.4 & 4.20 & 150 \\
\hline
\end{tabular}

ingested by $36.4 \%$ of all specimens whereas fish (including both flesh fragments and whole fish consumed) were ingested by $47.6 \%$ of the P. squamosissimus analysed, these being the most frequent items consumed.

The most important food item in terms of volume was fish $(116.8 \mathrm{~mL})$, representing $71 \%$ of the total vol- ume consumed, followed by insects $(44.8 \mathrm{~mL} ; 27.2 \%)$ (Table 1).

In terms of dry weight, the relative importance of each food item was fish $(13,530 \mathrm{mg})$ representing $91.1 \%$ of total biomass followed by insects $(5,120 \mathrm{mg} ; 34.4 \%)$ (Table 1). 
Fish was the food item consumed in the greatest number. In all, 129 whole fish were found in the stomachs of $P$. squamosissimus analysed, followed by dipteran pupae and larvae, which totalled 71 organisms (Table 1).

Comparing the food items consumed in different periods of the year (Figure 2) it was found that in February the most frequent items were Campsurinae (Ephemeroptera nymphs) (62.2\%), egg-mass Ephemeroptera (37.7\%), fish flesh $(26.2 \%)$, white fish $(16.3 \%)$ and plant material (13.1\%); whereas in June fish flesh became the most important item, with a frequency of occurrence of $33.8 \%$, followed by Campsurinae (Ephemeroptera nymphs) (32.2\%). In September there was a change in diet with predominance of Campsurinae (Ephemeroptera nymphs)
(23\%) and Chironomidae pupae (23\%). In November the most frequent item was again fish flesh $(57.1 \%)$ followed by plant material $(28.5 \%)$, Coelotanypus sp. (Chironomidae larvae) (14.2\%) and Ablabesmyia sp. (Chironomidae larvae) (11.4\%).

The highest values of the Alimentary Index were found in June (0.47) and November (0.39) for the item fish flesh fragments. On the other hand the item Ephemeroptera (Campsurinae nymphs) was the most representative in the months February and June with 0.30 and 0.45 , respectively (Table 2 ).

The population of $P$. squamosissimus was divided into 7 standard length classes (Class 1: 8.3 to $12.3 \mathrm{~cm}$,

Table 2. Values of the Alimentary Index (IAi) for items of the P.squamosissimus diet in four periods of the year 2003 (February, June, September and November) in Bariri reservoir, Tietê River basin, São Paulo State, Brazil.

\begin{tabular}{|c|c|c|c|c|}
\hline Periods & February & June & September & November \\
\hline \multicolumn{5}{|l|}{ Fish } \\
\hline Fish flesh fragments & 0.26 & 0.47 & 0.38 & 0.39 \\
\hline Fish (unidentified) & 0.16 & $<0.01$ & 0.03 & 0.08 \\
\hline Plagioscion squamosissimus (fish fry) & 0.11 & - & - & $<0.01$ \\
\hline Cichlidae & $<0.01$ & $<0.01$ & - & - \\
\hline Siluriformes & $<0.01$ & - & - & - \\
\hline \multicolumn{5}{|l|}{ Ephemeroptera } \\
\hline Campsurinae fragments (nymphs) & 0.30 & 0.45 & 0.13 & 0.12 \\
\hline Egg mass & 0.16 & - & 0.42 & $<0.01$ \\
\hline \multicolumn{5}{|l|}{ Odonata } \\
\hline Phyllocycla sp. (nymphs) & $<0.01$ & $<0.01$ & $<0.01$ & 0.01 \\
\hline Libellulidae (nymphs) & $<0.01$ & - & - & - \\
\hline Odonata nymphs fragments & - & $<0.01$ & - & - \\
\hline \multicolumn{5}{|l|}{ Diptera } \\
\hline Chironomidae (pupae) & $<0.01$ & $<0.01$ & $<0.01$ & $<0.01$ \\
\hline Coelotanypus sp. (larvae) & - & $<0.01$ & - & 0.11 \\
\hline Ablabesmyia sp. (larvae) & - & $<0.01$ & - & 0.10 \\
\hline Cryptochironomus sp. (larvae) & - & $<0.01$ & - & 0.02 \\
\hline Chaoborus sp. (larvae) & - & - & $<0.01$ & $<0.01$ \\
\hline Chaoborus sp. (pupae) & - & - & $<0.01$ & $<0.01$ \\
\hline Ceratopogonidae (larvae) & - & $<0.01$ & $<0.01$ & $<0.01$ \\
\hline Asheum sp. (larvae) & $<0.01$ & - & - & - \\
\hline Brundiniella sp. (larvae) & - & $<0.01$ & - & $<0.01$ \\
\hline Goeldichironomus sp. (larvae) & $<0.01$ & - & - & - \\
\hline Harnischia sp. (larvae) & - & - & - & $<0.01$ \\
\hline \multicolumn{5}{|l|}{ Zooplankton } \\
\hline Notodiaptomus sp. (Copepoda Calanoida) & - & - & $<0.01$ & - \\
\hline Calanoida fragments & - & - & $<0.01$ & - \\
\hline \multicolumn{5}{|l|}{ Others } \\
\hline Trichoptera (larvae) & - & $<0.01$ & $<0.01$ & $<0.01$ \\
\hline Macrobrachium sp (Crustacea) & - & - & $<0.01$ & - \\
\hline Plant material & $<0.01$ & 0.06 & $<0.01$ & 0.10 \\
\hline Detritus & $<0.01$ & - & - & $<0.01$ \\
\hline Insect fragments & - & $<0.01$ & 0.18 & 0.03 \\
\hline
\end{tabular}


Class 2: 12.4 to $16.4 \mathrm{~cm}$, Class $3: 16.5$ to $20.5 \mathrm{~cm}$, Class 4: 20.6 to $24.6 \mathrm{~cm}$, Class 5: 24.7 to $28.7 \mathrm{~cm}$, Class $6: 28.8$ to $32.8 \mathrm{~cm}$, Class $7: 32.9$ to $36.9 \mathrm{~cm}$ ).

It was observed that the fish belonging to the smaller size classes had no preference for any specific food, being characterised by a generalist feeding habit. On the other hand, the adult fish from larger classes the displayed a preference for the items fish flesh, indicating a more specialized diet.

Comparing the diet of the specimens of each size class sampled in each season (four sampling periods) is pre-
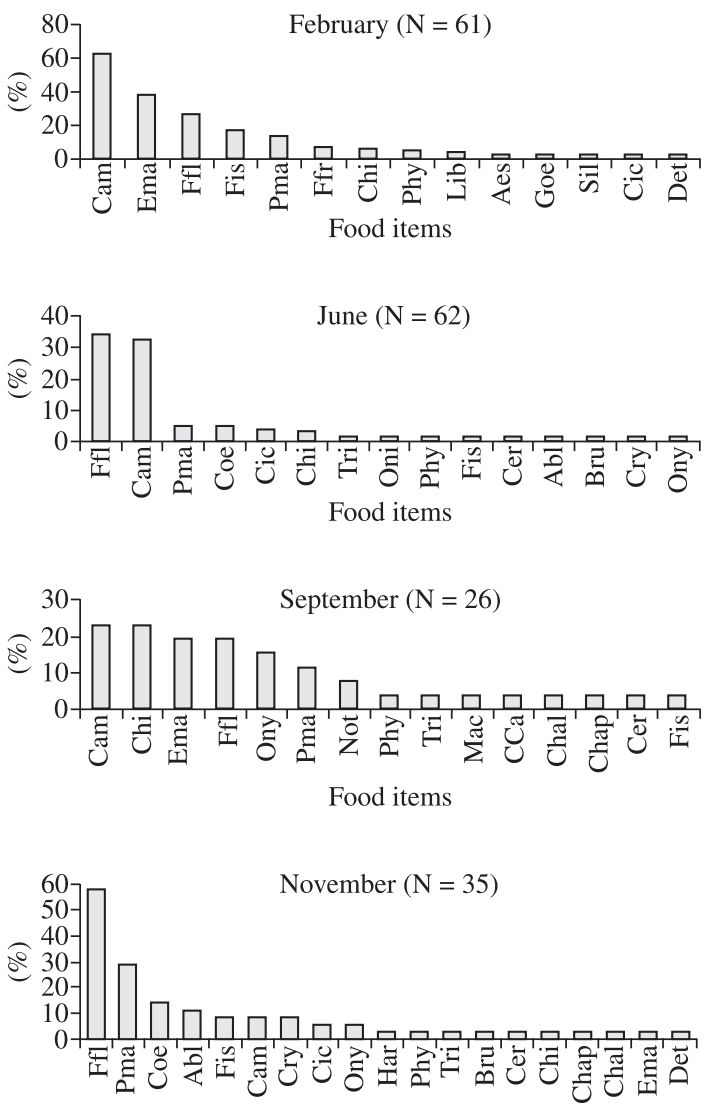

Food items

Figure 2. Overall frequency of occurrence (\%) of main food items consumed by Plagioscion squamosissimus in Bariri reservoir, basin sampled in different periods of the year 2003: Cam $=$ Campsurinae $($ Ephemeroptera $) ;$ Ema $=$ Egg mass (Ephemeroptera); Ffl = Fish flesh fragments; Fis = Fish (unidentified); Ffr $=$ Fish fry (Plagioscion squamosissimus) ; Cic = Cichlidae; Sil = Siluriformes; Ony = Odonata nymph fragments; Phy = Phyllocycla $\mathrm{sp}$. (Odonata) Lib = Libellulidae (Odonata); Oin = Other insect fragments; $\mathrm{Chi}=$ Chironomidae (pupae); Abl = Ablabesmya sp. (Diptera); Aes = Aeshum sp. (Diptera); Coe = Coelotanypus sp. (Diptera); Chal = Chaoborus sp. $($ Diptera larvae); Chap = Chaoborus sp. (Diptera pupae); Cry = Cryptochironomus sp. (Diptera); Goe = Goeldichironomus sp. (Diptera); Cer $=$ Ceratopogonidae (Diptera); Not $=$ Notodiaptomus $\mathrm{sp}$. (Copepoda Calanoida); $\mathrm{CCa}=$ Copepoda Calanoida fragments; Det $=$ Detritus; Pma $=$ Plant material . sented in Figure 3. It was found that in February (end of summer and rainy season) fish, Ephemeroptera and plant material were consumed by all size classes, except class 5 , which consumed plant material only. In June (winter and dry season), individuals belonging to the classes 1, 3 and 4 consumed mainly fishes, Ephemeroptera, Diptera and insect fragments. Individuals from class 2 consumed only Ephemeroptera, Trichoptera and insect fragments. Larger individuals consumed only the item fish. In September (early spring and at the end of the dry season), individuals from class 1 and 2 consumed mainly Diptera, zooplankton (Copepoda) and plant material. The item fish was consumed by classes 3, 4, 6 and 7 .
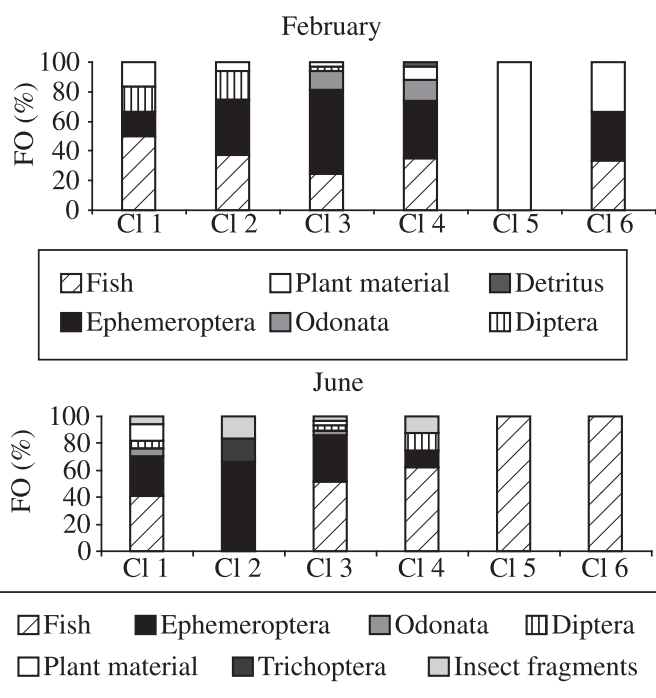

September

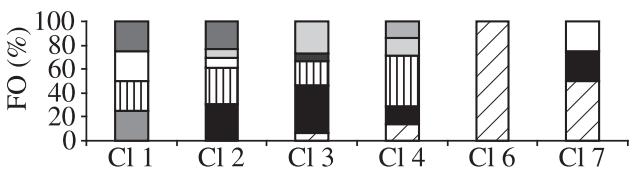

\begin{tabular}{|c|c|c|}
\hline$\square$ Fish & $\square$ Plant material & $\square$ Zooplankton \\
\hline سDiptera & Ephemeroptera & $\square$ Crustacea \\
\hline$\square$ Odonata & $\square$ Insect fragments & $\square$ Trichoptera \\
\hline
\end{tabular}

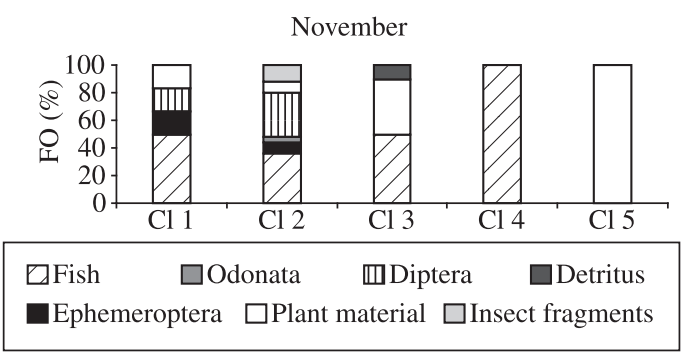

Figure 3. Main food items consumed by different size classes in the Plagioscion squamosissimus population in Bariri Resevoir, Tietê River Basin, São Paulo State, in each of the four periods sampled in the year 2003. 
Individuals from class 4 were the only ones consuming the item Crustacea (Macrobrachium sp). In November Diptera and Ephemeroptera were consumed only by the smaller individuals (classes 1 and 2). The item fish was consumed by classes 1, 2 and 3, whereas class 4, only plant material (Figure 3).

Statistical analysis showed that there were significant differences in the food items consumed along the year in Bariri Reservoir. The null hypothesis was rejected $\left(\mathrm{Xr}^{2}=3.72 ; \mathrm{P}<0.05\right)$.

A dendrogram obtained by cluster analysis (UPGMA) of the presence or absence of the food items consumed by all 7 size classes of $P$. squamosissimus in Bariri Reservoir showed two distinct groups, one formed by the small size classes (1, 2, 3 and 4) and the second formed by the large ones (5, 6 and 7) (Figure 4).

The results from the Friedman Test applied to compare the diet of the different size classes also evidenced that there were significant changes in the food preference among the size classes and therefore the null hypothesis was rejected $\left(\mathrm{Xr}^{2}=6.48 ; \mathrm{P}<0.05\right)$.

\section{Discussion}

On the basis of the results obtained in Bariri reservoir, P. squamosissimus can be considered a fish of piscivorous feeding habit. Nevertheless, it also consumes a number of other food items, including many aquatic insects (Ephemeroptera, Odonata, Trichoptera e Diptera) and plant material.

This species was classified as piscivorous and generalist by Hahn et al. (1997), who also noted the occurrence of insects as secondary items. According to Braga (1998), the diet composition of $P$. squamosissimus in Barra Bonita Reservoir is essentialy fish, with a minor consumption of Odonata and Ephemeroptera nymphs.

In the Northeast of Brazil the food of P. squamosissimus is mainly based on fish, insects and crustaceans (Braga, 1990). On the other hand fishes

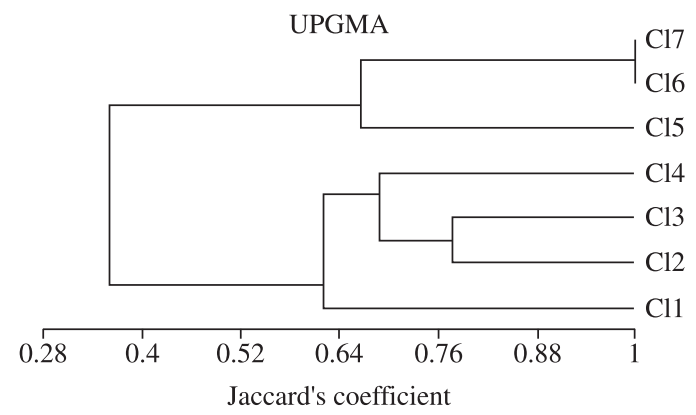

Figure 4. Dendrogram resulting from Cluster Analysis (UPGMA), based on the presence and absence of food items consumed by Plagioscion squamosissimus, in Bariri reservoir, Tietê River Basin, São Paulo State. (Cophenetic Coeficient $=0.90$ ). constituted a small fraction in the diet of the "corvina" (P. squamosissimus) in many water bodies in the Amazon region, being crustaceans the dominant item (Goulding and Ferreira, 1984).

The variety of items found in the diet of P. squamosissimus in Bariri Reservoir indicates a wide spectrum of food items consumed and consequently a low feeding specificity. According to Wootton (1999) and Abelha et al., (2001) classification of fishes feeding habits this species can be considered a generalist with a wide food spectrum.

Although most individuals consumed a variety of food resources, there was a noticeable shift in their diet during ontogenetic development. These changes consisted mainly of the greater exploitation of Diptera larvae (Chaoboridae and Chironomidae) and other aquatic insects (immature forms) by the juveniles of the smaller size classes and the switch to a fish dominated diet in the adults, characterising a wide spectrum of food items in the young and a more specialised, piscivorous diet in the adults.

The consumption of chironomids gradually decreased with the increasing size of $P$. squamosissimus specimens. As predacions fish grow, feeding on small organisms becomes less advantageous (Hynes, 1950). The capture of such organisms, unless very abundant, results in low forage efficiency and energy return. According to Wootton (1999), the ontogenetic changes in fish diet are also determined by morphological changes and greater locomotory ability in the larger fish.

Similar ontogenetic changes in the diet of P. squamosissimus were reported by Hahn et al. (1997), in a stretch of Rio Paraná (Porto Rico region, Paraná, Brazil) with juveniles mainly consuming insects and adults preferring to catch fish.

Besides fish and aquatic insects, plant material was an important resource used by $P$. squamosissimus, particularly in the months of February and November. The ingestion of this resource in these months can be influenced by the increase in the rainfall precipitation and greater input to the reservoir. Allochtonous plant matter (leaves, flowers, roots, and fruits) falling onto the surface can be carried to the reservoir during the rainy season. Uieda and Kikuchi (1995), studying the input of allochtonous material in a creek, concluded that the input occurs in the rainy season.

The food plasticity of $P$. squamosissimus evidenced in the present study might at least partially explain the reasons why this species has been so successful in this Reservoir.

Although it is generally believed that Plagioscion squamosissimus would be a good option regarding the selection of a species to be introduced in reservoirs, because it occupies mainly the deep limnetic region, usually not used by other fish, our study shows that actually, both juveniles and adults can compete for food, to the detriment of several native species populations. For this reason, $P$. squamosissimus should not be introduced into 
basins other than those to which they are native, as for example that of the Paraná River.

Acknowledgements - The authors thank CAPES for the scholarship to the first author, to the Ministry of the Environment (MMA/BIRD/GEF) project PROBIO, to CNPq/PRONEX for financial support; to Dra ${ }^{\mathrm{a}}$. Fernanda Teixeira Marciano for helping with the statistical analysis.

\section{References}

ABELHA, MCF., AGOSTINHO, AA. and GOULART, E., 2001. Plasticidade trófica em peixes de água doce. Acta Scientiarium, vol. 23 , no. 2, p. 125-434

AGOSTINHO, AA., HAHN, NS., GOMES, LC. and BINI, LM., 1997. Estrutura trófica. In VAZZOLER, AEAM., AGOSTINHO, AA. and HAHN, NS. (Orgs.). A Planície de inundação do alto rio Paraná: aspectos físicos, biológicos e socioeconômicos. Maringá: EDUEM. p. 229-248.

AGOSTINHO, AA., JULIO JR., HF. and TORLONI, CE., 1994. Impactos causados pela introdução e transferência de espécies aquáticas: uma síntese. In: Seminário Sobre a Fauna Aquática e o Setor Elétrico Brasileiro. Caderno II. Rio de Janeiro: COMASE/Eletrobrás.

AGOSTINHO, AA. and JULIO Jr, HF., 1999. Peixes da Bacia do Alto Paraná. In LOWE- MCCONNELL, RH. (Ed.). Estudos Ecológicos de Comunidades de Peixes Tropicais. São Paulo: EDUSP. 534 p.

BRAGA, FMS., 1990. Aspectos da reprodução e alimentação de peixes comuns em um trecho do rio Tocantins entre Imperatriz e Estreito, estados do Maranhão e Tocantins, Brasil. Revista Brasileira de Biologia = Brazilian Journal of Biology, vol. 50, no. 3 , p. 547-558.

1998. Alimentação de Plagioscion squamosissimus (Osteichthyes, Sciaenidae) no reservatório de Barra Bonita, Estado de São Paulo. Iheringia Série Zoologia, vol. 84, no. 1, p. 11-19.

BRAGA, FMS. and BRAGA, MAAS., 1987. Estudo do hábito alimentar de Prionotus punctatus (Bloch, 1797) (Teleostei, Triglidae), na região da ilha Anchieta, Estado de São Paulo, Brasil. Revista Brasileira de Biologia = Brazilian Journal of Biology, vol. 47, no. 1/2, p. 31-36.

CESP, 1998. A Conservação e Manejo nos Reservatórios: limnologia, ictiologia e pesca. São Paulo. 163 p.

ESPÍNDOLA, ELG., BRANCO, MCB., FRACÁCIO, R., GUNTZEL, AM., MORETTO, EM., PEREIRA, RHG., 2003. Organismos Aquáticos. In RAMBALDI, DM. and OLIVEIRA, DAS. (Orgs.). Fragmentação de ecossistemas: causas, efeitos sobre a biodiversidade e recomendações de políticas públicas. Brasília: MMA/SBF. 510 p.
GOULDING, M. and FERREIRA, EJG., 1984. Shrimp-eating fishes and a case of prey-swiching in Amazon river. Revista Brasileira de Zoologia, vol. 2, no. 3, p. 85-97.

HAHN, NS., AGOSTINHO, AA. and GOITEIN R., 1997. Feeding ecology of curvina Plagioscion squamosissimus (Heckel, 1840) (Osteichthyes, Perciformes) in the Itaipu reservoir and Porto Rico floodplanin. Acta Limnologica Brasiliensia, vol. 9, p. 11-22.

HYNES, HBN., 1950. The food of freshwater sticklebacks (Gasterosteus aculeatus and Pigosteus pungitius), with a review of method used in studies of the food of fishes. Journal of Animal Ecology, vol. 19, no. 1, p. 36-56.

HYSLOP, EJ., 1980. Stomach contents analysis, a review of methods and their application. Journal of Fish Biology, vol. 17, p. 411-429.

KAWAKAMI, E. and VAZZOLER, G., 1980. Método gráfico e estimativa de indice alimentar aplicado no estudo de alimentação de peixes. Boletim do Instituto Oceanográfico, vol. 29, no. 2, p. 205-207.

LOWE-MCCONNELL, RHL., 1987. Ecological Studies in Tropical Fish Communities. Cambridge: Cambridge Univ. Press. 382 p.

PRAT, N. and RIERADEVALL, M., 1995. Life cycle and production of Chironomidae (Diptera) from Lake Banyoles (NE Spain). Blackwell Science Ltda. Freshwater Biology, vol. 33, p. 511-524.

ROCHA, O., ESPÍNDOLA, ELG., FENERICH-VERANI, N., VERANI, JR., and RIETLZLER, AC., 2005. O problema das invasões biológicas em águas doces. In ROCHA, O., ESPÍNDOLA, ELG., FENERICH-VERANI, N., VERANI, JR., and RIETZLER, AC., (Orgs). Espécies Invasoras em Águas Doces: estudos de caso e propostas de manejo. São Carlos: Universidade Federal de São Carlos. p. 9-12.

SIEGEL, S. and CASTELLAN Jr., JN. 2006. Estatística não paramétrica para ciências do comportamento. Porto Alegre: Artmed e Bookman. 448 p.

SMITH, WS., ESPÍNDOLA, ELG. and ROCHA, O., 2005. As introduções de espécies de peixes exóticos e alóctones em bacias hidrográficas brasileiras. In ROCHA, O., ESPÍNDOLA, ELG., FENERICH-VERANI, N., VERANI, JR., and RIETZLER, AC. (Orgs). Espécies Invasoras em Águas Doces: estudos de caso e propostas de manejo. São Carlos: Universidade Federal de São Carlos. p. 25-44.

STURGES, HA., 1926. The choice of a class interval. Journal of the American Statistical Association, vol. 21, p. 65-66.

UIEDA, VS. and KIKUCHI, RM. 1995. Entrada de material alóctone (detritos vegetais e invertebrados terrestres) num pequeno curso de água corrente na cuesta de Botucatu, São Paulo. Acta Limnologica Brasiliensia, vol. 7, p. 105-114.

WOOTTON, RJ., 1999. Ecology of teleost fish. London: Chapman and Hall. 404 p. 